\title{
Zofia Kawczyńska-Butrym*
}

iD https://orcid.org/0000-0001-7073-5772

\section{DZIECI W MIGRACJI - CO O NICH WIEMY?}

\begin{abstract}
Abstrakt. Przy omawianiu procesów migracji często pomija się problem dzieci i nieletnich, choć globalne dane ukazują wzrost liczby procesów, w których uczestniczą. W 2017 r. szacowano, że $30 \mathrm{mln}$ dzieci żyje poza krajem pochodzenia. Ukazuje to znaczenie migracji, w której bierze udział najmłodsze pokolenie. Celem artykułu przeglądowego jest ukazanie szerokiego kontekstu badań podejmowanych w literaturze przedmiotu dotyczącego sytuacji dzieci uczestniczących w migracji. Sytuacje te obejmują zmiany podstawowych relacji społecznych, proces edukacji oraz konsekwencje i ryzyka zdrowotne dzieci. Dodatkowo zwrócono uwagę, że skala tych zmian i ich specyfika zależna jest od tego, w jaki sposób dziecko uczestniczy w migracji. Uwzględniono trzy sytuacje: dziecko w migracji rodzinnej, dziecko samotnie migrujące i dziecko pozostawione w kraju rodzinnym przez jednego lub oboje migrujących rodziców.
\end{abstract}

Słowa kluczowe: dziecko w migracji, migracja i dzieci, dzieci „w ruchu”, dzieci i młodzież w migracji.

\section{Uzasadnienie podjętego tematu i metoda przeglądu literatury}

W kilku ostatnich dekadach problemy społeczne łączone z dziećmi odnosiły się w wielu badaniach socjologicznych w Polsce do kwestii biedy (Warzywoda-Kruszyńska 2010). Podkreślano szczególnie trudną sytuację dzieci, zwłaszcza w enklawach ubóstwa i w kontekście międzypokoleniowego dziedziczenia biedy. Jeszcze w początkach tego wieku wskazywano, że co drugim beneficjentem pomocy społecznej w jednym z dużych polskich miast było dziecko (Kruszyński, Starzyńska 2010: 31). Jednocześnie, wraz z wejściem Polski w struktury Unii Europejskiej, wyraźnie wzrosła liczba procesów migracji zarobkowej pokolenia osób dorosłych. Miały one także wpływ na zmianę sytuacji życiowej wielu dzieci.

* Prof. dr hab., Instytut Socjologii, Wydział Filozofii i Socjologii, Uniwersytet Marii Curie-Skłodowskiej, pl. Marii Curie-Skłodowskiej 4, 20-031 Lublin, e-mail: zofkaw@wp.pl 
Czy sytuacja dziecka miała znaczenie w decyzjach migracyjnych i w jakim zakresie procesy migracyjne oddziałały na sytuację dzieci? Jaka jest wiedza na temat funkcjonowania dzieci, nie tylko polskich, w globalnych procesach migracji? $\mathrm{Na}$ tak sformułowane pytania znamy już wiele odpowiedzi, ale nie wszystkie. W tej sytuacji podejmuję próbę analizy dotychczasowego stanu i kierunków badań problemów dzieci migrujących.

Procesy migracji z różnych przyczyn i z różnym nasileniem trwają już od wieków, jednak nigdy, jak ma to miejsce $w$ ostatnich latach, nie miały twarzy dziecka. Czy faktycznie dzieci nie migrowały, czy tylko nie interesowano się ich sytuacją i nie poddawano jej analizie, ponieważ w odbiorze społecznym zawsze towarzyszyły rodzicom? Choć migracje dzieci nie są zjawiskiem nowym, gdyż jako pracownicy uczestniczyły już w masowych migracjach epoki kolonialnej, a także obecnie pracują zarobkowo (Hindman 2009), to dopiero w ostatnich latach zwrócono większą uwagę na dzieci w różny sposób uczestniczące w migracjach. W 2017 r. stwierdzono bowiem, że wśród 258 mln osób na całym świecie mieszkających poza krajem urodzenia dzieci stanowiły aż $30 \mathrm{mln}$ (Children in migration 2018). W tym około $10 \mathrm{mln}$ to dzieci, które zostały przymusowo wysiedlone z własnych krajów (UNICEF 2016). Jednocześnie tylko w 2015 r. 96 tys. dzieci bez opieki ubiegało się o azyl w UE (Children in migration 2018).

Oczywiste stają się więc pytania, jaka jest sytuacja i jakie są konsekwencje doświadczane przez dzieci, które w różny sposób uczestniczą w migracji, oraz czy sytuacja dziecka migrującego jest w pełni zależna od rodziny, jeśli z nią migruje, czy też jest wynikiem oddziaływania nowego środowiska, do którego dziecko trafia, i różnicy kulturowej między środowiskiem pochodzenia a środowiskiem imigracji, czy zależy od tego, z kim i dlaczego migruje, lub jak przeżywa rozłąkę z tymi, którzy wyemigrowali.

Dla rozpoznania problemów powiązanych z uczestnictwem dzieci w migracji dokonałam przeglądu literatury, uwzględniając różne portale i odnosząc się do słów kluczowych: child in migration, migration and children, children in move, children and adolescents on the move, dokumentów dotyczących dzieci w migracji: UNICEF, IOM, UNHCR, UE, Komisja Europejska (Eur.Com) oraz nielicznych dotychczas publikacji zwartych, w których uwzględnione zostały łącznie różne formy uczestnictwa dzieci w migracji.

W literaturze i dokumentach przedstawiany jest wpływ różnych rodzajów uczestnictwa dziecka w ruchu (child on the move) na zmianę jego położenia społecznego, sytuację społeczną, emocjonalną i zdrowotną. W wielu publikacjach wykorzystywana jest metoda ilościowa. Przykładem są coroczne, międzynarodowe podłużne badania porównawcze, prowadzone w 150 krajach w latach 2006-2016 (Burrone $\mathrm{i}$ in. 2018). Rzadziej stosowana jest metoda jakościowa, a przykładem są obszerne badania oparte na 282 wywiadach indywidualnych i dyskusjach w grupach fokusowych, co pozwoliło autorom na pogłębienie wiedzy na temat sytuacji dzieci migrujących z Afryki (Bueno 2019). Również polskie publikacje 
dotyczące migracji dzieci wykorzystują zarówno metody ilościowe, jak i jakościową oraz mieszane metody badań empirycznych.

Dotychczas w analizach skupiano się na przyczynach, przebiegu oraz indywidualnych społecznych, a szczególnie ekonomicznych konsekwencjach migracji osób dorosłych, także na ich migracji z dziećmi lub bez nich. Równolegle, w związku z uchodźcami napływającymi do Polski, opisywano problemy dzieci uchodźców (Januszewska 2010). W wyniku tego wiemy już dość dużo o sytuacji dzieci migrujących z ojcem, matką lub z całą rodziną, a także o sytuacji tych dzieci, które pozostały w kraju (Danilewicz 2006). Mimo to jeszcze przed dekadą podkreślano, że ,istnieją poważne luki w naszej wiedzy o dzieciach, które migrują" (White i in. 2011). Od tego czasu podjęto liczne badania, które w części uzupełniły te braki (Donato, Sisk 2015). Między innymi w 2018 r. ukazała się książka napisana przez duży zespół autorów, w której problem migracji dzieci przedstawiono jako znaczący nowy aspekt międzynarodowej mobilności ludzi w różnych krajach i na wielu kontynentach (Bhabha i in. 2018). Mniej wiemy o dzieciach samotnie migrujących. Ostatnio coraz więcej dowiadujemy się o tych, które wracają do kraju wraz z reemigrującymi rodzicami (Szydłowska i in. 2019), a także o specyfice problemów łączących się z powrotami dzieci repatriantów (Książek 2019).

\section{Dzieci w migracjach}

\footnotetext{
Dzieci w różny sposób uczestniczące w migracjach są coraz częściej uznane za wymagające szczególnej uwagi grupy wrażliwe (vulnerable group) (IOM 2013).
}

Na wstępie należy zwrócić uwagę, że choć dzieciństwo jest definiowane jako okres do 15. roku życia, to Konwencja ONZ odnosząca się do migracji poszerza kategorię wieku i definiuje dziecko jako człowieka poniżej 18. roku życia. W badaniach procesów migracji do grona dzieci wliczani są zatem również nastolatkowie, po to, ,aby zapewnić ochronę i prawa tak szerokiej grupie wiekowej, jak to możliwe" (Child and young migrants 2019). Przy tak definiowanym ujęciu dzieciństwa poszerzona została kategoria wiekowa osób, które, szczególnie w przypadku samotnie migrujących, podlegają uwadze i analizie badaczy.

W opracowaniach wyrażany jest pogląd, że decyzje migracyjne rodziców są wynikiem ich oceny aktualnej i prognozowanej sytuacji rodziny, a troska o przyszłość dzieci ma wpływ na decyzje migracyjne. Jednym z przykładów takiego podejścia jest wtórna analiza danych z powtarzanej ankiety prowadzonej w 150 krajach przez Instytut Gallupa w latach 2006-2016 (Burrone i in. 2018). Dane te prowadzą do wniosku, że w wielu przypadkach decyzje migracyjne pokolenia dorosłych są wyraźnie skorelowane z obecnością w ich gospodarstwie domowym dziecka do 15. roku życia oraz że decyzje migracyjne rodziców mają źródło 
w obawach o przyszłość dzieci w kraju rodzinnym, szczególnie gdy dotyczy to niekorzystnego wskaźnika zadowolenia z systemu edukacji. Ponadto celem tych decyzji jest poprawa ,subiektywnego samopoczucia i zadowolenia z wolności osobistej" dzieci (Burrone i in. 2018). Podobnie według innych autorów, wspólna migracja $z$ dziećmi motywowana jest oczekiwaniem poprawy i wzmocnienia ich długoterminowych szans życiowych, głównie w wyniku zwiększonych możliwości inwestowania w edukację (Graham, Yeoh 2013), a szerzej - w kapitał osobisty i społeczny dzieci (Rossi 2008). Biorąc pod uwagę ten kierunek analiz, znajdujemy odpowiedź na postawione wcześniej pytanie, czy sytuacja dzieci w Polsce, szczególnie w pierwszych latach po akcesji do Unii Europejskiej, miała wpływ na procesy i decyzje migracyjne podejmowane przez polskich rodziców. Przytoczone badania pozwalają udzielić pozytywnej odpowiedzi, przy założeniu, że decyzje migracyjne motywowane były nie tylko przymusem ekonomicznym, ale też przyszłością i interesem dzieci.

Przedstawiana w literaturze analiza konkretnych problemów związanych z procesem migracji najmłodszych i młodocianych grup migrantów uwzględnia co najmniej trzy kategorie dzieci, w zależności od charakteru ich uczestnictwa w migracji. Są to:

- dzieci migrujące z rodzicami (niezależnie od przyczyn migracji: zarobkowa, uchodźstwo, repatriacja, reemigracja),

- dzieci samotnie migrujące,

- dzieci biernie uczestniczące w migracji, a więc te, które nie uczestniczą w niej bezpośrednio, lecz doświadczają jej problemów w związku z migracją jednego lub obojga rodziców (określane w Polsce mianem eurosierot).

W każdej z tych kategorii należy zwrócić uwagę na „zyski” dzieci migrujących, jak również specyfikę ich problemów. Jak wskazują badania, migracja dziecka „może być zarówno pozytywnym, jak i negatywnym doświadczeniem, jest to złożony proces z trudnościami i możliwościami, które wpływają na jego rozwój” (Gomez 2015). Z jednej strony warto podkreślić, że dzieci w procesach migracji są charakteryzowane nie tylko jako grupa wrażliwa, bezbronna, wymagająca pomocy innych, ale też zwraca się uwagę na ich aktywną rolę w podejmowaniu decyzji migracyjnych i w mediacjach kulturowych między dorosłymi członkami rodziny i społeczeństwem przyjmującym (White i in. 2011). Badania uwzględniają także różnorodność czynników związanych z ryzykiem ich rozwoju i funkcjonowania. Czynniki te obejmują szereg złożonych sytuacji, które tworzą grupy problemów społecznych powiązanych z procesami migracji i z nich wynikających. Należy jeszcze dodać, że zwraca się dodatkowo uwagę na dzieci powracające z migracji i dzieci repatriowane (UNICEF 2005; Książek 2019; Szydłowska $i$ in. 2019). W literaturze sygnalizowana jest sytuacja dzieci uchodźczych obciążonych traumą wojny (Januszewska 2010). Jednak w artykule skupiam się głównie na dzieciach $\mathrm{w}$ globalnych procesach migracji zarobkowych, zgodnie $\mathrm{z}$ kryterium rodzaju uczestnictwa: migrujące z rodzicami, samotnie lub biernie. 


\section{Dzieci migrujące z rodzicami}

Migrację dziecka z rodzicami traktuje się na ogół jako migrację rodzinną, czyli migrację jednostki rodzinnej jako całości. Przy czym obecność dziecka w migracji rodziców jest interpretowana przede wszystkim jako towarzyszenie głównemu migrantowi, a jednocześnie pozostawanie w zależności od niego. Sytuację, w której członkowie rodziny przyjmowani są w kraju imigracji „razem z głównym migrantem”, określa się terminem ,rodzina towarzysząca” (UNICEF 2016). Również w sensie prawnym współmałżonkowie i małoletnie dzieci są uważani za „osoby pozostające na utrzymaniu”, w związku z czym przysługuje im taki sam status, jaki uzyskuje główny imigrant. Nie bez znaczenia jest obserwacja zjawiska określanego jako „delokalizacja klasy społecznej” imigrantów w kraju imigracji (Eade i in. 2006). Delokalizacja jest charakterystyczna przede wszystkim dla pierwszego okresu imigracji. Wprawdzie dotyczy rodziców, ale rzutuje na społeczne i materialne usytuowanie dziecka $\mathrm{w}$ procesie migracji, a jak ostatnio stwierdzono, również na doświadczane przez nie nierówności ekonomiczne i zagrożenie marginalizacją (Strzemecka, Slany 2019). W innych publikacjach znajdujemy bardziej rozbudowaną charakterystykę położenia części dorosłych imigrantów w kraju pobytu: „Marginalizacja i dyskryminacja w kraju osiedlenia, bariery w dostępie do usług socjalnych, wyzwania dla praw do obywatelstwa i tożsamości, niepewność ekonomiczna rodziców oraz dyslokacja społeczna i kulturowa" (UNICEF 2005). Jeśli przyjmiemy, że dzieci uzyskują ten sam status co rodzice, to wszystkie te cechy położenia mogą mieć wpływ na sytuację i pozycję wielu z nich.

Jednak wspólny wyjazd za granicę z rodzicami wydaje się sytuacją dość komfortową dla dzieci, ponieważ obecność rodziców daje im poczucie bezpośredniego kontaktu oraz bezpieczeństwa w nowym miejscu życia. Okazuje się też, że rodzice są „bardzo ważni w okresie wkraczania w nową rzeczywistość społeczną, kulturową" (Krasnodębska 2016). A jednocześnie, co podkreślono wcześniej, migracja z dziećmi ma na celu ich szeroko rozumiane dobro, kontynuację bezpośredniej opieki i jest formą inwestycji w przyszłość dziecka.

Nie oznacza to jednak braku problemów, z którymi zderza się ono samo, dlatego w omawianiu literatury skupiam się na trudnościach doświadczanych przez dzieci. Jednocześnie zdaję sobie sprawę, że artykuł stanowi zasygnalizowanie problemów, a nie ich dogłębną analizę. Jak bowiem informuje UNICEF, nie do końca znana jest skala zjawiska, ponieważ „dane dotyczące emigracji rodzinnej są obecnie niekompletne z powodu ograniczonej zdolności większości krajów lub braku woli politycznej do gromadzenia danych" na ten temat (UNICEF 2005). Nie znaczy to jednak, że zagadnienie dziecka w ramach migracji rodzinnej nie jest podejmowane. Charakteryzując ogólnie opisywane w literaturze zmiany i problemy, obserwowane przez różnych autorów w głównych obszarach społecznej aktywności dziecka migrującego, należy wymienić trzy z nich: relacje społeczne, proces edukacji i zdrowie. 
Pierwszy problem wiąże się ze stwierdzeniem, że w wyniku emigracji osłabieniu ulegają dotychczasowe kontakty z członkami dalszej rodziny, z rówieśnikami i przyjaciółmi w kraju pochodzenia. Ale dzięki wizytom w kraju rodzinnym i rozwijającej się sieci elektronicznej (Podgórska 2019) mogą być nadal podtrzymywane. Jednak dotychczasowa grupa rówieśnicza nie jest już bezpośrednim i stałym obszarem wsparcia (Haikkola 2011). Jednocześnie w nowym, obcym sobie środowisku dzieci wchodzą $\mathrm{w}$ rówieśnicze relacje społeczne, nie zawsze otwarte i przyjazne. Ponieważ uczeń-imigrant „wnosi do otoczenia część własnej kultury" (Krasnodębska 2016: 298), wiele zależy od tego, jak zostanie zaakceptowany przez środowisko szkolne. Jest to najczęściej niezależne od młodego imigranta. Jak sygnalizują badania, ,zdobycie akceptacji jest bardzo trudne, jeśli nie zna się specyfiki lokalnych subkultur młodzieżowych, obowiązującego stylu ubierania, miejscowego slangu" (Jaroszewska 2013). Natomiast wykluczenie czy brak akceptacji przez rówieśników staje się dla młodych imigrantów źródłem głębokich przeżyć i stresów, wynikających z poczucia stygmatyzacji, dyskryminacji, i jest jedną z głównych barier adaptacji do nowego środowiska (Haavind i in. 2015). Dotyczy to również dzieci repatriantów. Dzieci bywają naznaczane ze względu na utrwalone w kraju przyjmującym stereotypy „obcego”, a nawet „inny akcent lub popełnione błędy” (Książek 2019). Barierą może być także konfrontacja standardów ubóstwa wiązana $\mathrm{z}$ krajem pochodzenia i różnic $\mathrm{w}$ statusie społecznym i symbolach statusu ekonomicznego młodych imigrantów w porównaniu z dziećmi i młodzieżą miejscową. Okazuje się bowiem, że dochodzenie rodziny migracyjnej do „wyrównywania” statusu społecznego podlegającego degradacji w kraju przyjmującym, wspomnianej wcześniej „,delokalizacji klasy społecznej”, w porównaniu do statusu wcześniej zajmowanego w kraju pochodzenia, szacowane jest na około 10 lat (Schenker 2012). Można przewidywać, że jest to także często okres, w którym dochodzi do dalszego przełamywania przez dzieci barier i wzajemnej akceptacji w relacjach rówieśniczych.

Po dłuższym czasie dzieci zaczynają „oceniać pobyt w nowym kraju jako pozytywną zmianę życiową" (Krasnodębska 2016: 298). Pozostaje jednak pytanie, w jakiej grupie głównie następuje akceptacja - czy pojawia się ona w relacjach z rówieśnikami miejscowymi w kraju przyjmującym, czy w grupie rówieśników imigranckich, czy tylko wśród rówieśników-imigrantów z grupy etnicznej lub narodowej. Niestety, nie znalazłam badań na ten temat, dzięki którym można by było odpowiedzieć na to pytanie. Ponieważ w wielu krajach europejskich „bycie imigrantem zwiększa ryzyko odrzucenia i w konsekwencji dezaprobaty" dla członków niektórych mniejszości etnicznych, rośnie dystans między migrantami a społeczeństwem (Markowska-Manista, Sawicki 2019). Dlatego też należy przewidywać, że akceptacja rówieśnicza dzieci także dokonuje się głównie w relacjach etnicznych lub narodowych. Jak się też wydaje, „wewnątrz-imigracyjnej” akceptacji sprzyjają funkcjonujące wspólnoty imigranckich mieszkańców, które Sylwia Urbańska (2015) nazywa „gettami migracyjnymi w metropoliach Eu- 
ropy i Ameryki". Są to diaspory imigranckie funkcjonujące w krajach imigracji (Waldstein 2008), co wskazuje nie tylko na przyciągające oddziaływanie sieci migracyjnych, ale też na silniejsze więzi wewnątrz grup pochodzenia niż ze społeczeństwem przyjmującym.

Drugi problem to obszar edukacji. Jest on, jak wspomniano, jednym z ważniejszych motywów, które mogą skłaniać rodziców do migracji z dziećmi, gdy ci uznają, że kraj rodzinny nie gwarantuje oczekiwanego poziomu nauczania, a przez to też awansu społecznego. W zasadzie w nowym kraju nie ma trudności w wysłaniu dziecka do szkoły, ponieważ konwencje międzynarodowe zobowiązują kraje przyjmujące do zorganizowania nauki szkolnej dzieciom imigrantów. Formalnie też zakłada się pozytywny wpływ środowiska nauczania na proces adaptacji do nowych warunków życia. „Pobyt w szkole sprzyja nabywaniu kompetencji kulturowych i budowaniu kapitału społecznego" (Krasnodębska 2016: 297). Zakłada to również raport UNICEF, w którym podkreślono, że „migracja wpływa na wyniki w nauce dzieci, ich integrację społeczną i samopoczucie emocjonalne" (UNICEF 2005). Jednak dzieci migrujące napotykają, zwłaszcza w pierwszym okresie migracji, trudności z opanowaniem nowego języka i przystosowaniem do innego stylu nauczania. Pobyt w nowym kraju, w nowym środowisku szkolnym jest dla dzieci okresem „burzliwego przejścia”, stanowi szok kulturowy i powoduje silne przeżycia związane z przemocą i dyskryminacją oraz z zachwianiem poczucia tożsamości i przywiązania (Strzemecka, Slany 2019). Trudności mogą dotyczyć też relacji w instytucjach edukacyjnych, przy braku zaangażowania nauczycieli w rozwiązywanie powstających problemów (Waksmundzki 2014). Dzieje się tak, gdy nauczyciele i dyrekcja szkół, w których uczą się dzieci imigrantów, nie dostrzegają dyskryminacji, agresji werbalnej i fizycznej lub nie potrafią jej zaradzić, natomiast uczestniczące w migracji „dzieci strasznie przeżywają emigrację. Stres w szkole jest tak ogromny, że wymiotują rano i płaczą" (Kaw czyńska-Butrym 2009). Świadomość przemocy doświadczanej w środowisku szkolnym zaburza również proces dalszego funkcjonowania dzieci imigranckich, nie tylko w grupie rówieśniczej (Strzemecka, Slany 2019). Już te przykłady sygnalizują, że mimo migracji rodzinnej, a więc fizycznej bliskości rodziców, uczestnictwo w migracji może zaburzać poczucie bezpieczeństwa dziecka oraz poprzednią względną równowagę emocjonalną i aksjologiczną młodych ludzi. Wymaga więc od młodego pokolenia imigrantów, zwłaszcza nastolatków, dostosowania się do nowych warunków, zasad, norm i czasem odmiennych standardów funkcjonowania w grupie. Obserwowane jest to szczególnie wówczas, gdy oddziałują dwa relatywnie różne i odległe konteksty kulturowe i normatywne, postrzegane przez dziecko jako niejednorodne, sprzeczne i konkurencyjne. $\mathrm{Z}$ jednej strony jest to rodzina $\mathrm{i}$ jej system norm, wartości i kontroli, $\mathrm{z}$ drugiej strony - działają wartości i wzorce, jakie proponuje atrakcyjny nowy świat, i silnie oddziałuje presja środowiska rówieśniczego spoza kręgu pochodzenia. Przy znacznej różnicy kultur między krajem pochodzenia i krajem pobytu występuje 
rozbieżność między modelem i oczekiwaniami rodziny a stylem życia młodzieży w nowym kraju. Wynikające z tego problemy dotyczą także samej szkoły, działań i programów, które zgodnie z poprawnością polityczną pomijają (np. w Wielkiej Brytanii) historię kraju przyjmującego, co nie sprzyja procesowi integracji (Balicki 2010: 206-209). Życie na pograniczu dwóch światów oznacza dla wielu młodych ludzi „kulturowy szpagat”, ostry konflikt między wartościami wolności jednostki w jednych krajach a nakazem bezwarunkowego posłuszeństwa rodzicom $\mathrm{w}$ innych, między programami szkolnymi dotyczącymi sfery seksualności a obowiązującym w tej sferze tabu w rodzinie pochodzenia (Jaroszew ska 2013: 69). Konsekwencją tych rozbieżności mogą być trudności procesu identyfikacji i niepewność własnej tożsamości kulturowej - kim jestem, jak mam żyć? To prowadzi do zaburzeń zachowania w stosunku do jednego z systemów odniesień normatywnych i agresji wobec otoczenia, jak też autoagresji. Życie w szpagacie międzykulturowym ujawniać się też może zaburzeniami odżywiania: bulimią lub anoreksją (Bulik 2006), jak również psychosomatycznymi bólami głowy, pleców, brzucha, które „najostrzej występują u azjatyckich dziewcząt”, a nawet ucieczką z domu i próbą samobójczą (Black 1992). Pojawiają się także różnego rodzaju napięcia emocjonalne, które odpowiadają za zwiększenie częstotliwości występowania różnego rodzaju zaburzeń zdrowia psychicznego u dzieci i młodzieży uczestniczących w migracjach w porównaniu do dzieci i młodzieży w kraju ich pochodzenia i w kraju ich aktualnego pobytu (Carballo i in. 1998). Już te dane, które ukazują sytuację szkolną i życie w dysonansie kulturowym dzieci i młodzieży w nowym kraju, zwracają uwagę na trzeci problem doświadczany przez dzieci i młodzież, w różny sposób uczestniczące w migracji - problem zdrowia.

Ogólnie oczekuje się, że migracje mają korzystny wpływ na zdrowie dzieci, które migrują, ponieważ przybywają one do krajów z dostępem do lepszej opieki zdrowotnej, szerszej wiedzy na temat zdrowia, a często też stosowania właściwych praktyk higienicznych (Rossi 2008: 38). Dlatego, jak wskazuje literatura, nie można jednostronnie opisywać sytuacji dziecka migrującego z rodzicami jako ryzyka zagrażającego jego zdrowiu. Przede wszystkim decyzje rodziców o rodzinnej migracji mają na celu m.in. dostęp dziecka do korzystniejszego, zdaniem rodziców, systemu opieki zdrowotnej i poprawę standardu życia, również oddziałującą pozytywnie na jego zdrowie. Są badania, które potwierdzają słuszność tych decyzji. Dokumentują to też wyniki badań imigrantów z Ameryki Południowej (Donato, Sisk 2015) oraz meksykańskich imigrantów w Stanach Zjednoczonych, wśród których obserwuje się niższe wskaźniki umieralności noworodków, śmiertelności niemowląt oraz ich wyższą masę urodzeniową niż w kraju pochodzenia (Hildebrandt, McKenzie 2005). Jest to także widoczne w badaniach prowadzonych $\mathrm{w}$ Pakistanie, gdzie potwierdzono wyższe parametry wzrostu dziewcząt $\mathrm{z}$ rodzin migrujących niż w przypadku rodzin, z których rodzice nie migrowali (UNICEF 2008). 
$\mathrm{Z}$ drugiej strony uczestnictwo dziecka $\mathrm{w}$ migracji, analogicznie do sytuacji osób dorosłych (Hindman 2009; Kawczyńska-Butrym 2019), stwarza wiele sytuacji ryzyka zdrowotnego oraz stanowi „poważne zagrożenia dla dzieci i ich zdrowia”, ponieważ dzieci rodziców migrujących „są szczególnie podatne na alkoholizm, narkotyki, ciąże nastolatek i inne problemy" (UNICEF 2008). Dotyczy to także problemów psychicznych, a szczególnie ryzyka związanego ze zdrowiem psychicznym (Farley i in. 2005; Gonneke, Vollebergh 2008) oraz kryzysem w rozwoju osobowości (Książek 2019: 229). Badania prowadzone w Portugalii sygnalizowały częstsze zgłaszanie tego typu problemów przez młodzież imigrancką pochodzącą z siedmiu wielokulturowych grup (775 osób badanych) niż przez młodzież miejscową (320 osób badanych). Przy czym głównym czynnikiem występowania tego typu problemów u młodzieży imigranckiej okazało się poczucie dyskryminacji, trudności w kontaktach społecznych i problemy behawioralne (Neto 2009). W tej sytuacji nie mogą zaskakiwać informacje na temat częstotliwości samobójstw w tej grupie młodzieży. Już w końcu lat 90. minionego wieku sygnalizowały to statystyki samobójstw wśród dzieci tureckich imigrantów (Carballo i in. 1998: 941).

Jednocześnie badania wskazują na współwystępujące z migracją ryzyko pogorszenia stanu zdrowia dzieci związane ze statusem socjoekonomicznym rodziców, przynależnością do grupy etnicznej, dostępem do opieki zdrowotnej (Javier i in. 2010). Różnice dotyczą krajów, które otworzyły swój rynek pracy dla pracowników cudzoziemskich i zabezpieczają świadczenia socjalne oraz opiekę zdrowotną (na przyjętych w kraju zasadach) dla nich i dla ich rodzin, oraz przypadków migracji nielegalnej, gdzie brak jest tego rodzaju gwarancji ze strony kraju przyjmującego. Opracowania różnicują sytuację ochrony zdrowia dzieci w zależności od legalności lub nielegalności migracji zarobkowej ich rodziców (Simek 2006). Przede wszystkim podkreślają ograniczenia dostępu do opieki zdrowotnej dzieci rodziców nielegalnie przebywających w konkretnym kraju, poza sytuacją zagrożenia życia i ewentualną profilaktyką, która obejmuje jedynie dzieci uczestniczące $\mathrm{w}$ nauce szkolnej. Nie można też pominąć kwestii różnic kulturowych, które mogą ograniczać korzystanie z usług medycznych (Jabłecka 2012; Kawc zyńska-Butrym 2019). Ponadto brak opieki lekarskiej nad częścią populacji dzieci migrujących może powodować zaniedbania w zapobieganiu chorobom, opóźniać proces terapii i ograniczać jej skuteczność, a także zwiększyć ryzyko chorób zakaźnych wśród rówieśników w kraju przyjmującym.

Przedstawione trzy obszary problemów dzieci migrujących: relacje społeczne, edukacja i zdrowie są jednak wyraźnie zróżnicowane ze względu na rodzaj uczestnictwa w migracji. Analiza literatury pozwala jeszcze podjąć próbę opisu sytuacji dzieci samotnie migrujących oraz tej grupy dzieci, które bezpośrednio nie uczestniczą w migracji, lecz odczuwają jej konsekwencje i w różny sposób ich doświadczają, ponieważ zostały pozostawione w kraju przez migrujących rodziców. 


\section{Dzieci samotnie migrujące}

Dzieci-migranci są narażone na nadużycia, handel ludźmi i wykorzystywanie, zwłaszcza jeśli podróżują samotnie (Child and young migrants 2019).

Dziecko samotnie migrujące to szczególna sytuacja osoby poniżej 18. roku życia, pozbawionej obecności rodziców lub bezpośredniego opiekuna, ale też, w rozumieniu międzynarodowych definicji, sytuacja przekraczania granicy państwowej przez osobę nieletnią, gdy nie opiekuje się nią „osoba dorosła, która zgodnie z prawem lub zwyczajem jest do tego zobowiązana” (UNHCR 1997). Taka interpretacja pozwala oddzielić samotnie migrujące dziecko od dziecka uprowadzonego przez inne osoby dorosłe lub migrującego w towarzystwie dorosłych, którzy nie są zobowiązani do opieki nad nim. Problem samotnych migracji nieletnich bywa wynikiem ich samodzielnych decyzji migracyjnych (dotyczy to migrujących nastolatków) podejmowanych w różnych celach, także w celu podjęcia pracy zarobkowej poza krajem, by finansowo wesprzeć rodzinę (Camacho 1999), bywa również efektem przypadków losowych (bez względu na wiek dziecka) - a więc przykładowo sytuacji, gdy rodzice zostali zatrzymani, deportowani lub zaginęli/zmarli w trakcie podróży.

Zjawisko samotnej migracji dzieci i nieletnich, niezależnie od sytuacji, która je spowodowała, jest dynamiczne i ma charakter globalny. Na przykład na początku XXI w. szacowano, że „tylko w Europie Zachodniej przebywa około 100 tys. dzieci rozdzielonych z rodzicami, które poszukują azylu, a w krajach rozwiniętych jest około półtora miliona nastoletnich uchodźców" (Lalak 2007: 272). W ostatnich latach oszacowano, że liczba nieletnich wjeżdżających w ciągu jednego roku na obszar Unii Europejskiej między 2013 a 2015 r. wzrosła z 13800 osób rocznie aż do 96000 osób (Children in migration 2018).

Przyczyn samodzielnych decyzji migracyjnych osób nieletnich upatruje się również $\mathrm{w}$ doświadczaniu przez nie przemocy (jako ofiary) i działań przestępczych (jako sprawcy). W każdej z tych sytuacji nieletni stara się zerwać przynajmniej część dotychczasowych kontaktów, by uniknąć prześladowcy lub odpowiedzialności za własny czyn. Dodatkowo, co obserwowane jest w przypadku samotnie migrujących 14-17-letnich chłopców z krajów Ameryki Południowej (Gwatemali, Salwadoru, Hondurasu), samotna migracja bywa ucieczką przed gangami, które usiłują ich rekrutować (Menjívar, Perreira 2017). W wyniku doświadczeń poprzedzających migrację oraz doświadczeń w trakcie migracji pojawiają się poważne problemy emocjonalne towarzyszące nieletnim ze względu na niepewność dnia codziennego i przyszłości, a szczególnie brak wsparcia ze strony bliskich. Przemoc, w tym przemoc i wykorzystywanie seksualne zwłaszcza dziewcząt (Menjívar, Perreira 2017), oraz dramatyczne momenty związane z warunkami życia (bezdomność, głód) powodują wysoki poziom stresu i poczucie braku bezpieczeństwa, wywołane separacją od rodziców i osamotnieniem 
(Wernesjö 2012). Samotni nieletni migranci napotykają także trudności w kraju pobytu. Wynika to zarówno z ograniczenia dostępu do wielu usług i ograniczenia mechanizmów radzenia sobie w obcym, nieznanym środowisku (Bueno 2019), jak i z niekorzystnego wizerunku przedstawianego przez media. Nieletni migrujący prezentowani są $\mathrm{w}$ nich jako potencjalni przestępcy i nosiciele „chorób zakaźnych, które mogą zagrażać dobru mieszkańców w krajach przyjmujących" (Wernesjö 2012). Cały ten kontekst towarzyszący samotnie migrującym dzieciom i nastolatkom ukazuje najtrudniejsze scenariusze, które stają się ich udziałem i z którymi muszą się zmierzyć.

Jeszcze inna sytuacja dotyczy samotnej dalszej migracji dzieci we wspomnianych przypadkach losowych, obejmujących nagłą utratę rodzica/rodziców. Jeśli pozbawione opieki dzieci nie zostaną nią otoczone przez instytucje imigracyjne w kraju pobytu, ich sytuacja staje się analogiczna do sytuacji samotnie migrujących nieletnich, ze wszystkimi wymienianymi w literaturze negatywnymi dla nich konsekwencjami.

\section{Dzieci biernie uczestniczące w migracjach (przykład tzw. eurosierot)}

Na ogół brak jest szczegółowych informacji o liczebności dzieci pozostających w kraju, podczas gdy jedno lub oboje rodzice decydują się na migrację. Łączą je jednak podobne odczucia. Przede wszystkim dzieci pozostawione w kraju doświadczają zdecydowanej poprawy sytuacji materialnej i ogólnego standardu życia rodziny. Nadsyłane przez migrujących rodziców przekazy pieniężne pozwalają na zwiększanie konsumpcji, poprawę sytuacji mieszkaniowej, zwiększają dostęp do edukacji i opieki zdrowotnej. Dla rodziców jest to sposób inwestowania w kapitał ludzki i przyszłość dzieci (Rossi 2008). Jak zauważają Nicole Hildebrandt i David McKenzie (2005), „przekazy pieniężne mogą zrekompensować matczyną nieobecność". Jednocześnie należy podkreślić, że w przypadku pozostania dziecka w kraju pochodzenia unika ono wielu trudności i obciążeń, których doświadczają dzieci migrujące z rodzicami i te, które migrują samotnie. Przede wszystkim ich dotychczasowe więzi społeczne nie ulegają większym zmianom lub gwałtownym ograniczeniom, jak miało to miejsce w poprzednich kategoriach nieletnich migrantów. Dziecko zostawione w kraju przez migrującego rodzica pozostaje $\mathrm{w}$ dotychczasowym środowisku znajomych, sąsiadów i dalszej rodziny, ale też $\mathrm{w}$ większości $\mathrm{w}$ dotychczasowym środowisku rówieśniczym, wśród znanych kolegów, przyjaciół w szkole i poza nią. Poza przypadkami, gdy przekazane jest pod opiekę dziadków lub innych osób mieszkających poza miejscem jego dotychczasowego zamieszkania, nie musi poznawać ani adaptować się do nowego środowiska społecznego. Pozostaje również w znanej sobie przestrzeni fizycznej, która nie wymaga rozpoznawania obcej topografii przy poruszaniu się w nowym miejscu zamieszkania. Nadal też pozostaje w znanym sobie świecie 
wartości - znanych norm, wzorów zachowań i oczekiwań. Unika więc wielu barier i zagrożeń, które są udziałem dzieci czynnie uczestniczących w migracjach, co starano się wyeksponować w dotychczasowych analizach.

Nie oznacza to jednak, że bierne uczestnictwo w migracji pozbawione jest zagrożeń. Literatura ujawnia wiele niekorzystnych konsekwencji dla funkcjonowania takich dzieci. Niezależnie od miejsca, w którym dziecko pozostaje, traci ono bezpośredni kontakt z migrującymi rodzicami/rodzicem, co nie jest dla niego obojętne. Dziecko czuje się odrzucone i niekochane. Tym bardziej że „dzieciom bardzo łatwo wmówić: mama cię porzuciła i sobie pojechała" (Urbańska 2015). Dlatego dziecko głęboko przeżywa „ograniczenia lub odcięcie kontaktu emocjonalnego z rodziną" (Devakumar i in. 2018). Jak wskazały badania prowadzone na Filipinach, szczególnie w przypadku migracji matek, u dzieci obserwowano „gorsze wyniki w szkole i tendencję do powstawania różnych problemów społecznych" (Rossi 2008). Rozłąka jest więc źródłem silnych przeżyć emocjonalnych i niesie wiele zagrożeń zdrowia o charakterze psychosomatycznym. W literaturze medycznej referowane są przypadki związku między migracją rodziców a zaburzeniami zdrowia psychicznego, $\mathrm{w}$ tym depresją u dziecka pozostawionego w kraju pochodzenia (Dereszak-Kozanecka 1994).

Wyniki badań prowadzonych przez polskich i zagranicznych autorów pozwalają zwrócić uwagę na niekorzystny wpływ biernej migracji („,eurosierot”) na sytuację szkolną i zachowanie (Danilewicz 2006; Walczak 2008; Dąbrowska 2011). W trakcie migracji rodziców „rozpada się” dom rodzinny, dający dziecku i młodemu człowiekowi poczucie bezpieczeństwa i wsparcia w trudnym okresie dorastania. Z jednej strony w publikacjach opisywana jest sytuacja emocjonalna dziecka (towarzysząca tęsknota), z drugiej - przedstawia się sytuację szkolną, niekorzystny wpływ na wyniki nauczania, stosunek do nauki szkolnej (wagarowanie, spóźnianie się na lekcje, konflikty w klasie) (Dąbrows ka 2011: 157), a także ryzyko uzależnień. Zwraca się też uwagę, że dzieci pozostające $\mathrm{w}$ kraju rodzinnym w jeszcze jeden sposób zderzają się z problemem migracji - w kontaktach z przybywającymi do kraju dziećmi imigrantów, żyją bowiem „,w społecznościach, które wysyłają lub przyjmują dużą liczbę migrantów” (UNICEF 2005).

\section{Zakończenie}

Problem migracji dzieci i ich doświadczeń należy rozpatrywać w kontekście ogólnych procesów migracyjnych, sytuacji materialnej rodzin migrujących i oczekiwań rodziców oraz podejmowanych przez nich decyzji o migracji z dziećmi czy bez nich. Dotyczy też samodzielnych decyzji nastolatków o migracji. Jednak migracje dzieci mają swoją specyfikę. Zmiana miejsca i społeczeństwa, w którym się znajdują, zmienia ich relacje społeczne, oddziałuje na proces edukacji i zdrowie. 
Przedstawiona analiza poświęcona została głównie migracjom zarobkowym, analogicznie do tego, jak jest omawiana w cytowanej literaturze.

Odpowiadając na postawione na początku artykułu pytanie, można stwierdzić, na podstawie literatury dotyczącej migracji dzieci, że szczególnie w pierwszych latach po włączeniu Polski w struktury Unii Europejskiej rodziny w decyzjach migracyjnych brały pod uwagę dość trudną sytuację ekonomiczną oraz niepewność o przyszłość dzieci. W literaturze podkreśla się zarówno poprawę sytuacji materialnej dzieci, które pozostawały w kraju i korzystały z transferów pieniężnych nadsyłanych przez migrujących rodziców, jak i relatywną (w porównaniu z krajem pochodzenia) poprawę sytuacji dzieci migrujących z rodzicami. Natomiast decyzja o wspólnej z dziećmi lub samodzielnej migracji rodziców rodziła problemy, które stawały się doświadczeniem nieletnich, ponieważ dotyczyła konsekwencji w różnych obszarach aktywności młodych osób - w relacjach społecznych, edukacji i zdrowiu.

Kończąc analizę, nie można przyjąć, że dzieci i nieletni w różny sposób uczestniczący w procesach migracji są uwikłani wyłącznie w ryzyka i zagrożenia. W literaturze zwraca się uwagę na fakt, że to właśnie obecność dzieci w rodzinie lub one same pełnią aktywną rolę $w$ decyzjach migracyjnych. $Z$ drugiej strony dzieci i nieletni szybciej niż dorośli uczą się obcego języka, są mediatorami kulturowymi między dorosłymi członkami rodziny a społeczeństwem przyjmującym, a także biorą aktywny udział w podtrzymywaniu więzi ponadnarodowych z krajem pochodzenia. Poprawa sytuacji materialnej i jakości życia rodziny, dostęp do korzystniejszych standardów opieki zdrowotnej w bogatszych krajach daje wielu osobom z młodego pokolenia migrantów możliwość różnie rozumianej promocji zdrowia. Ponadto życie w kraju imigracji jest też okresem nabywania wielu nowych kompetencji społecznych. W literaturze zwraca się uwagę, że w przypadku migracji z rodzicami „większość migrujących dzieci ma szanse na rozwój i pozytywnie przyczynia się do tworzenia nowych społeczności” (Bueno 2019). Zdecydowanie mniej czynników ryzyka związanych jest z pozostawieniem dziecka w kraju, nie licząc sfery emocjonalnej. $Z$ największym ryzykiem strat i z ogromnymi obciążeniami spotyka się dziecko samotnie migrujące. Wymaga ono zwiększonej uwagi służb społecznych i państwowych w drodze (on the move) do kraju docelowego i w kraju imigracji.

\section{Bibliografia}

Balicki J. (2010), Imigranci z krajów muzułmańskich w Unii Europejskiej. Wyzwania dla polityki integracyjnej, Wydawnictwo Uniwersytetu Kardynała Stefana Wyszyńskiego, Warszawa.

Bhabha J., Kanics J., Hernández D.S. (red.) (2018), Research Handbook on Child Migration, Edward Elgar Publishing, Cheltenham-Northampton.

Black J.A. (1992), Potrzeby medyczne dzieci mniejszości etnicznych w Wielkiej Brytanii, „Aktualności Pediatryczne", nr 1(1), s. 67-93. 
Bueno O. (2019), ,, No Mother Wants Her Child to Migrate”. Vulnerability of Children on the move in the Horn of Africa, UNICEF Office of Research - Innocenti, Florence.

Bulik C.M. (2006), Eating Disorders in Immigrants: Two Case Reports, „International Journal of Eating Disorders", nr 6(1), s. 133-141.

Burrone S., D'Costa B., Holmqvist G. (2018), Child-related concerns and migration decisions: evidence from the Gallup world poll, UNICEF Office of Research - Innocenti, Florence.

Camacho A.Z.V. (1999), Family, Child Labour and Migration: Child Domestic Workers in Metro Manila, „Childhood”, nr 3(1), https://doi.org/10.1177/0907568299006001005

Carballo M., Divino J.J., Zeric D. (1998), Migration and Health in the European Union, „Tropical Medicine and International Health", nr 3(12), s. 936-944.

Child and young migrants (2019), Migration Data Portal, https//migrationdataportal.org/ themes/child-and-young-migrants (dostęp: 10.03.2020).

Children in migration, in 2017 EU actions to protect children in migration (2018), https://fra. europa.eu/en/publication/2018/migrant-children (dostęp: 10.03.2020).

Danilewicz W. (2006), Sytuacja życiowa dzieci w rodzinach migracyjnych, Wydawnictwo Uniwersyteckie Trans Humana, Białystok.

Dąbrowska A. (2011), Sytuacja rodzinna i społeczna dzieci rodziców migrujacych zarobkowo z województwa świętokrzyskiego, Akademia Przedsiębiorczości, Kielce.

Dereszak-Kozanecka E. (1994), Sytuacja rodzinna pacjentów młodzieżowych z jednym rodzicem na emigracji zarobkowej, „Postępy Psychiatrii i Neurologii”, nr 3(4), s. 465-467.

Devakumar D., Russell N., Murphy L., Wickramage K., Sawyer S.M., Abubakar I. (2018), Children and Adolescents on the Move: What Does the Global Compact for Migration Mean for Their Health?, „The Lancet. Child \& Adolescent Health”, nr 3(2), https://pubmed. ncbi.nlm.nih.gov/30528682/ (dostęp: 10.03.2020).

Donato K.M., Sisk B. (2015), Children's Migration to the United States from Mexico and Central America: Evidence from the Mexican and Latin American Migration, „Journal on Migration and Human Security", nr 3(1), s. 58-79.

Eade J., Drinkwater S., Garapich M.P. (2006), Polscy migranci w Londynie - klasa spoteczna $i$ etniczność, CRONEM, University of Surrey, Londyn.

Farley T., Galves A., Dickinson L.M., Perez M. de J. (2005), Stress, Coping and Health: a Comparison of Mexican Immigrants, Mexican-Americans, and non-Hispanic Whites, ,Journal of Immigrant and Minority Health", nr 7(3), s. 213-220.

Gomez L.C.A. (2015), Migration and Its Impact on Children's Lives. A Literature Review, University of Iceland, https://skemman.is/bitstream/1946/21378/1/loka\%20loka.pdf (dostęp: 10.03.2020).

Gonneke W.J.M., Vollebergh W.A.M. (2008), Mental Health in Migrant Children, „The Journal Child Psychology and Psychiatry", nr 49(3), s. 276-294.

Graham E., Yeoh B.S.A. (2013), Child Health and Migrant Parents in South-East Asia: Risk and Resilience among Primary School-Aged Children, „Asian and Pacific Migration Journal”, nr 22(3), s. 297-314.

Haavind H., Thorne B., Hollway W., Magnusson E. (2015), ,,Because Nobody Likes Chinese Girls": Intersecting Identities and Emotional Experiences of Subordination and Resistance in School Life, „Childhood”, nr 22(3), s. 300-315.

Haikkola L. (2011), Making Connections: Second Generation Children and the Transnational Field of Relations, ,Journal of Ethnic and Migration Studies”, t. 37, nr 8, s. 1201-1217.

Hildebrandt N., McKenzie D.J. (2005), The Effects of Migration on Child Health in Mexico, „Economia”, nr 6(1), https://econpapers.repec.org/paper/wbkwbrwps/3573.htm (dostęp: 10.03.2020). 
Hindman H.D. (red.) (2009), The World of Child Labor. A Historical and Regional Survey, Routledge, New York, https://doi.org/10.4324/9781315698779.

International Organization for Migration (IOM) (2013), Children on the Move, https:// publications.iom.int/books/children-move (dostęp: 10.03.2020).

Jabłecka B. (2012), Strukturalne i kulturowe bariery w dostępie imigrantów do opieki medycznej, Instytut Spraw Publicznych, Warszawa.

Januszewska E. (2010), Dziecko czeczeńskie w Polsce. Między trauma wojenna a doświadczeniem uchodźstwa, Wydawnictwo Adam Marszałek, Toruń.

Jaroszewska E. (2013), Migracje a zdrowie. Uwarunkowania kondycji zdrowotnej migrantów oraz bariery w korzystaniu z opieki medycznej, Oficyna Wydawnicza Aspra-JR, Warszawa.

Javier J.R., Huffman L.C., Mendoza F.S., Wise P.H. (2010), Children with Special Health Care Needs: How Immigrant Status Is Related to Health Care Access, Health Care Utilization, and Health Status, „Maternal and Child Health Journal”, nr 14(4), s. 567-579.

Kawczyńska-Butrym Z. (2009), Migracje. Wybrane zagadnienia, Wydawnictwo Uniwersytetu Marii Curie-Skłodowskiej, Lublin.

Kawczyńska-Butrym Z. (2019), Zdrowie migrantów i drenaż biatego personelu. Wyzwania dla zdrowia publicznego, socjologii zdrowia i zawodów medycznych, Wydawnictwo Uniwersytetu Marii Curie-Skłodowskiej, Lublin.

Krasnodębska A. (2016), Dzieci polskich imigrantów w Norwegii. Kwestie adaptacyjne i tożsamościowe, „Studia Migracyjne - Przegląd Polonijny”, nr 3(161), s. 283-307.

Kruszyński K., Starzyńska D. (2010), Zasięg biedy w Polsce - perspektywa porównawcza, „Praca Socjalna”, t. XXV, s. 21-35.

Książek J. (2019), Adaptacyjne problemy dzieci repatriantów na tle relacji rówieśniczych, „Studia Migracyjne - Przegląd Polonijny", t. XLV, nr 1(171), s. 215-233.

Lalak D. (red.) (2007), Migracja, uchodźstwo, wielokulturowość: zderzenie kultur we współczesnym świecie, Wydawnictwo Akademickie Żak, Warszawa.

Markowska-Manista U., Sawicki K. (2019), Migrant Children and Youth „On the Move”. Between the Legacy of the Past and Challenges of the Future, „Kultura i Edukacja”, nr 2(124), s. 9-23.

Menjívar C., Perreira K.M. (2017), Undocumented and Unaccompanied: Children of Migration in the European Union and the United States, „Journal of Ethnic and Migration Studies”, $\mathrm{nr}$ 45(2), s. 1-21.

Neto F. (2009), Predictors of Mental Health among Adolescents from Immigrants Families in Portugal, ,Journal of Family Psychology”, nr 23(3), s. 375-385.

Podgórska K. (2019), E-migracje. Nowe technologie w procesach migracji, „The Polish Migration Review - Polski Przegląd Migracyjny", nr 5, s. 4-15.

Rossi A. (2008), The Impact of Migration on Children Left Behind in Developing Countries: Outcomes Analysis and Data Requirements, ,SSRN Electronic Journal”, https://globalnetwork.princeton.edu/bellagio/Rossi.pdf (dostęp: 10.03.2020).

Schenker M.B. (2012), A Global Perspective of Migration and Occupational Health, „American Journal of Industrial Medicine", nr 53(4), s. 329-337.

Simek A. (2006), Health Care and the Most Common Physical and Mental Problems of Illegal Migrant Workers and Their Families, ,Family and Primary Care Review”, nr 8(3), s. 765-768.

Strzemecka S., Slany K. (2019), Doświadczanie nierówności w statusie społecznym i bullyingu $w$ środowisku szkolnym. Percepcja dzieci polskich imigrantów w Norwegii, „Studia Migracyjne - Przegląd Polonijny", nr 1(171), s. 149-170.

Szydłowska P., Durlik J., Grzymała-Moszczyńska H. (2019), Returning Children Migrants - Main Challenges in School Environment, ,Studia Migracyjne - Przegląd Polonijny”, t. XLV, nr 1(171), s. 171-192. 
UNICEF (2005), Children and Migration, UNICEF Office of Research - In nocenti, Florence, https://www.unicef-irc.org/article/606-migration-and-children.html (dostęp: 10.03.2020).

UNICEF (2008), Children and women left behind in labour sending countries: an appraisal of social risks, UNICEF, Division of Policy and Practice.

UNICEF (2016), For Every Child, End AIDS: Seventh Stocktaking Report, https://www.unicef.org/ reports/every-child-end-aids-seventh-stocktaking-report-2016 (dostęp: 10.03.2020).

United Nations High Commissioner for Refugees (UNHCR) (1997), Guidelines on Policies and Procedures in dealing with Unaccompanied Children Seeking Asylum, http:// www.unhcr.org/afr/publications/legal/3d4f91cf4/guidelines-policies-procedures-dealingunaccompanied-children-seeking-asylum.html (dostęp: 10.03.2020).

Urbańska S. (2015), O macierzyństwie na odległość, „Polityka”, 6 października, https:// www.polityka.pl/tygodnikpolityka/spoleczenstwo/1635381,1,dr-sylwia-urbanska-omacierzynstwie-na-odleglosc.read (dostęp: 10.03.2020).

Waksmundzki T. (2014), Problemy edukacyjne dzieci cudzoziemców w polskich szkołach, [w:] E. Ślachcińska, H. Marek (red.), Edukacja międzykulturowa w warunkach kultury globalnej. Od rozważań definicyjnych do praktycznych zastosowań, t. III, Wydawnictwo Wyższej Szkoły Bezpieczeństwa, Poznań, s. 255-260.

Walczak B. (2008), Społeczne, edukacyjne i wychowawcze konsekwencje migracji rodziców i opiekunów prawnych uczniów szkót podstawowych, gimnazjalnych i ponadgimnazjalnych, Wyższa Szkoła Pedagogiki Resocjalizacyjnej Pedagogium, Warszawa.

Waldstein A. (2008), Diaspora and Health? Traditional Medicine and Culture in a Mexican Migrant Community, „International Migration”, nr 46(5), s. 95-117.

Warzy wo da-Kruszyńska W. (2010), Od badań nad bieda do badań nad procesem dziedziczenia biedy - tódzka szkoła badań nad biedą i pomoca społeczna i jej rezultaty, „Praca Socjalna”, t. XXV, s. 5-20.

Wernesjö U. (2012), Unaccompanied Asylum-seeking Children: Whose Perspective?, „International Journal of Migration, Health and Social Care", nr 19(4), s. 495-507.

White A., Laoire N.C., Tyrrell N., Carpena-Méndez F. (2011), Children's Roles in Transnational Migration, „Journal of Ethnic and Migration Studies”, nr 37(8), s. 1159-1170.

\section{CHILDREN IN MIGRATION - WHAT DO WE KNOW ABOUT THEM?}

Abstract. When discussing migration processes, the problem of children and minors is often disregarded, although global data show the growing number of processes in which they participate. In 2017, it was estimated that 30 million children live outside their country of origin. This demonstrates the importance of migration in which the youngest generation participates. The aim of the review article is to show a broad context of the research undertaken in the literature on the situation of children participating in migration. Such situations include changes in basic social relationships, education process, and consequences and health risks of children. In addition, it was noted that the scale of these changes and their specific character depends on the manner in which a child participates in migration. Three situations were taken into account: a child in family migration, a single migrant child and a child left in their home country by one or both of the migrating parents.

Keywords: child in migration, migration and children, children on the move, children and young migrants. 